\title{
Foreword
}

\section{Anna Nasiłowska}

\section{The Post-Modern Man}

DOI: 10.18318/td.2017.en.2.1

n late 2014, Encyklopedia gender. Płeć w kulturze [Gender

Studies Encyclopedia: Gender in Culture] came into print. It offers a survey of contemporary inquiries into and examinations of gender in the Polish humanities, including contributions from feminist and gay studies scholars, as well as from experts belonging to other fields linked with their Western counterparts or, we may even say, inspirations. The compendium reveals a very significant disproportion. The entries discussing women and feminism are plenty, while the number of male-oriented entries is only a handful: Men's studies/Masculinity studies, Male feminism, Hegemonic masculinity, Homosexual literature, Sexism, Backlash, Homophobia, Homosociety, Phallogocentrism, and Fatherhood. And basically that is all. Far be it from me to criticize such a state of affairs, especially given the fact that I myself contributed to the book. Such a situation is a reflection of the asymmetry of academic interest in the constructs of masculinity and femininity. Masculinity has long been considered a certainty, an unconsciously internalized norm. We should also add that many of the inquiries launched from a feminist position often assumed the patriarchal norm as representative of the male position, even though that could be construed as a considerable simplification, even with regard to historical descriptions and periods in

\author{
Anna Nasiłowska \\ - Professor at the \\ Institute of Literary \\ Research of the Polish \\ Academy of Sciences. \\ She is a member of \\ the Literature and \\ Gender Research \\ Team, the deputy \\ editor of Teksty \\ Drugie, board \\ member of Polish \\ PEN and president \\ of the Association of \\ Polish Writers (since \\ 2017). Her recent \\ publications include \\ the poetry volumes \\ Żywioły [Elements] \\ (2014); Ciemne \\ przejścia [Dark \\ Passages] (2018) and \\ a book Dyskont słów \\ [Word Discount Store] \\ (2016). Co-editor \\ of Encyklopedia \\ gender [Gender \\ Encyclopedia] (2014) \\ and 44. Nowy kanon \\ [44. New Canon]. \\ Author of the \\ forthcoming Historia \\ literatury polskiej- \\ nowy zarys [History \\ of Polish Literature. \\ A New Perspective] \\ (2018).
}


time where the presence of women in culture was more a rare exception than the norm. Developing the parallel field of men's studies would definitely work towards assuaging that asymmetry, especially given the fact that the field is not emerging in a vacuum but is already deeply indebted to feminism - years of deliberations and discussions on the status of cultural gender, intersectionality, and the performatics of gender roles pursued on behalf of feminism certainly give it a head start.

The essays included in this issue were published in Polish mostly in the 2015/2 issue, but - as it is wont to happen - the subject seeped through to subsequent issues of our bimonthly journal. As was the case with feminist issues (but not in Polish literature exploring these issues), forming a research thesis was possible primarily through reference to Western efforts exploring similar problems. The authors cite Alex Hobbs's Masculinity: Studies and Literature (Literature Compass, 2013/4), the Handbook of Studies on Man and Masculinity (ed. M.S. Kimmel) lexicon, M.S. Kimmel's The History of Man: Essays on the History of American and British Masculinities, and many other inquiries in the field. Above all, the authors, fully convinced of the validity and value of such points of view, problematize the issue of masculinity in Polish literature.

The shifts taking place in Polish popular culture are definitely hard to ignore. Machismo has faded out of fashion, and the culture seems to promote male figures that would popularly be called softies or metrosexual men. These labels, devised by journalists, nearly overused to death in a variety of magazines, and almost invariably invoking American terms without Polish counterparts, put their emphases on different areas: a softie can be gay but does not have to, a metrosexual man is, to an extent, the modern dandy, rather undefined in his preferences. And more recently, we have been witnessing the rise of another label promoted by the media: the lumbersexual man, an urban type wearing lumberjack garb and a full beard. It may be that the reason behind his emergence is the need to manufacture demand for another type of clothes and paraphernalia. After all, the lumbersexual is just another in a gallery of similar social stereotypes that have been steadily pumped out by the media, including the 1990s yuppie (short for young urban professional), and the more recent hipster, a creature of the economic crisis and representative of the precariat, his uncertain future decided by unfair employment practices. The yuppie worked in a corporation, took out mortgages, climbed the corporate ladder, and avoided asking questions about the future. Ten, twenty years later, the hipster was left with co-working spaces, non-governmental organizations, and alternative culture.

Naturally, these terms belong to the media discourse and describe reality as much as they create it. Each one was devised across the other side of the Atlantic, each has its own essayist origin and its own developmental dynamics. Although metrosexuality has long been the subject of many a piece in lifestyle magazine and tabloids, the lumbersexual type has been more of a recent phenomenon and its 
fame seems to have fizzled out just as quickly as it emerged. If we examine terms like softie or metrosexual from the perspective of their ability to create demand, it will quickly become apparent that their potential in this matter is considerable. Men bearing these labels need a lot of cosmetic products and will not be satisfied with merely soap and a razor like their forefathers were. They will buy products and services that were once addressed only to women. That plus earrings, necklaces, maybe even rings - although that is not such a recent development, given that sevententh-century European fashions went as far as expecting men to wear lacy garments. Additionally, the metrosexual stereotype is supposed to abolish the domination of dark and subdued colors in menswear. These men will also require a range of cosmetic procedures, including manicures, facials, and hair removal, which could open up whole avenues of new profit opportunities. If we were to look closely at the demographic that the concept of "new man" targets the most, we would probably become somewhat suspicious that the concept itself is being advanced by a hidden advertising agenda and that the advent of lumbersexuality itself is nothing but an attempt at diversification and raking in a new segment of customers, mostly those dissatisfied with the previously dominant dandyish elegance.

It is not entirely clear to me whether these behaviors ever really took root in contemporary Poland. The entire issue is rather complicated - some fashions remain purely theoretical, yet drive specific trends. On the other hand, the approach to color in menswear actually changed in the $2014 / 2015$ season and one could spot more than a few men sporting bright orange sweaters. But do I personally know any softies? Well, maybe one. The same goes for the perfect hipster, an elusive creature seen only by magazine columnists who keep on producing stories about it. I have heard, however (from an acquaintance, but still), a story about a young beautician who had a male client ask her to remove hair from his entire body, including the most intimate areas. The story added that she was terrified at the request - which only testifies to the rarity of similar jobs. Most of the men I know would never visit a beautician, regardless of reason. Neither macho nor metrosexual, they are something in between, but on the other hand this is not a spectrum, so the matter gets even more difficult to pin down. Even if a man does not really go for the metrosexual style, it does not automatically make them a proponent of machismo. These "types" identified in literature tend to focus on social impulses manufactured by the economy. Veblen's 1899 opus, The Theory of the Leisure Class, exaggeratingly revealed the rampant, conspicuous consumption of the upper classes in the America. The more recent "types," emerging primarily in the American mainstream, reflect conspicuous consumption in times of globalization and are linked with issues related to contemporary identity as outlined by Anthony Giddens in Modernity and Self-Identity.

Curiously, no parallel and equally ostentatious types addressed to women have emerged in the same timeframe. Within the same period, women had to content themselves with the single woman (like Bridget Jones) and accomplished profes- 
sionals in pursuit of happiness - like the characters in Sex and the City. Consumerism has succeeded in colonizing the realm of womankind so that by now, there is no longer a need to convince women to subject themselves to the pressures of style and the ever-changing rhythms of fashion, which may augment their appeal, produce better sexual relationships, and improve (however briefly) their social status. On the one hand, investing in another pair of pumps seems ludicrous, while on the other, it may be perceived as wholly rational - at least as long as it translates into higher self-esteem and a greater chance of success. After all, enjoying the spoils of mass production is supposed to be the reward for our daily toils. And now, narcissistic men with a diminished sense of agency can also compensate through increased consumption.

While no one seriously posits that we are dealing with a "crisis of femininity," the notion of a "crisis of masculinity," however, keeps coming back not only in magazine columns but in serious sociological studies. One such inquiry can be found in Zbyszko Melosik's Kryzys męskości w kulturze współczesnej [The Crisis of Masculinity in Modern Culture]. Besides, one only has to look as far as the Internet to see what is what... I believe that at least three of the attempts to identify the reasons for the crisis are flawed: the first, revolving around the notion that traditional masculinity is in decline and that masculinity itself is in peril. Such a notion is, first and foremost, founded upon faulty reasoning. The second is a patently false interpretation that identifies liberal feminism as the reason for the crisis of masculinity, antagonizing men and women, which at its core would go against the fundamental principles and objectives of liberal feminism; additionally, such an interpretation clearly overestimates the influence of feminism. The third type of reasoning revolves around the claim that we are actually dealing with a crisis of heterosexuality, given the widespread and fiery debates over gender and homosexuality.

This current issue of Teksty Drugie is not dedicated to exploring the crisis of masculinity - we have not succumbed to such ideology. Rather, it investigates diverse, historic, and contemporary forms of masculinity and takes a closer look at the validity of using gender studies analyses in literary studies. 